\title{
Publication Program of the A.C.R.L.
}

Prepared by Miss Ethel M. Feagley, associate librarian, Teachers College, Columbia University, and member of the A.C.R.L. Publications Committee.

$\mathrm{T}$ He Publications Committee of the Association of College and Reference Libraries (hereinafter referred to as the Publications Committee) consists of a representative from each of the sections of the association and a chairman appointed annually by the president of the association. The representative of the association on the A.L.A. Editorial Committee and the editor of College and Research Libraries are ex officio, nonvoting members. To insure continuity in publication policy the appointment of the chairman is made from within the Publications Committee and the appointment of members is made on a rotation basis, two new members being appointed each year to replace two that are going out.

\section{Relationships with Other Publication Committees}

Three members of the committee were in attendance at the midwinter meeting of the A.L.A., on Jan. 31, 1943: Guy R. Lyle, chairman, Wharton Miller, and Ralph R. Shaw, together with Everett O. Fontaine, chief of the A.L.A. Publishing Department, who had been invited to join the group. . Discussion centered around plans of organization and definitions of policy. Believing that the lack of integration of the publishing interests of the several sections of the A.C.R.L. constitutes a serious defect in any program of effective publication for the division, the Pub- lications Committee drew up the following recommendations regarding its own organization which were approved by the Board of Directors of the A.C.R.L.:

I. Publication relations with the A.L.A. Editorial Committee.

I. That the Publications Committee submit all A.C.R.L. publications for A.L.A. publication to the A.L.A. Editorial Committee for final review and approval.

2. That in case of disagreement, the Publications Committee may:

(a) Appeal the decision of the Editorial Committee to the Executive Board of the A.L.A.

(b) Seek an outside publisher.

3. That the Publications Committee has the authority to submit publications to publishers other than the A.L.A. if this seems desirable for reasons other than the one mentioned above.

4. That the Publications Committee make all approaches to foundations, institutions, or other organizations and societies for aid in publication projects through the Executive Board of the A.L.A. with the approval of the directors of the A.C.R.L.

II. Publication relations with sections and publication committees of the A.C.R.L.

I. That all publishing ventures of the A.C.R.L. be cleared through and subject to the approval of the Publications Committee.

2. That, in case of disagreement, the section publication committee has the right of appeal to the Board of Directors of the A.C.R.L.

3. That, in order to insure continuity in publication policy, sections setting up publication committees in the future shall appoint someone from the Publications Committee to their committees.

\section{Wartime Program}

The Publications Committee wishes to emphasize again that it does not now con- 
template an elaborate program of publication planning. Any extended program of initiating publications and research would probably need funds from some external source. Such funds as are now available from internal sources should be devoted to the support and development of $\mathrm{Col}$ lege and Research Libraries. 'This is not to say that the Publications Committee is opposed to individual or organized research at this time. There is opportunity in a number of fields of the Association's activities for individual research and publication, and there are also many desirable publication projects beyond individual resources which must necessarily be planned and carried out with the help of organizations which are adequately equipped and financed. Since this is true, it would seem that the Publications Committee, representing all sections of the Association, would be the logical body to aid in planning and carrying out cooperative projects.

For a trial period, at least, the Publications Committee feels that its immediate task is to consider projects or publications that may be presented to it, either by individuals or organized groups of the Association of College and Reference Libraries, and to report such publications with recommendations to the A.L.A. Editorial Committee or to other appropriate publishing concerns. A number of proposals, received during the past five years at A.L.A. Headquarters, have been referred to the Publications Committee by the chief of the A.L.A. Publishing Department. They include:

\section{Agricultural Libraries-Manual}

Preparation of such a manual was discussed at Kansas City in 1938.

\section{Archives-Administration Manual}

A need for a manual on archive admin- istration was expressed in October 1939 in a statement made to Dr. Kuhlman by Miss Julia Schmitz of Whitman College Library, Walla Walla, Wash. Dr. Kuhlman passed the suggestion on to us with his endorsement.

\section{Bibliography}

The recommendation has been made by the Bibliography Committee that A.L.A. help finance a revision or supplement to Van Hoesen and Walter's Bibliography. A suggested procedure looking toward preparation of a manuscript, provided the A.L.A. is to publish the work, was agreed upon with Leland R. Smith, chairman of the Bibliography Committee, at the midwinter meeting, I940. Apparently no steps were taken by the committee or by the authors up to the close of August 1942.

\section{Bibliographical Terms-Dictionary}

In 1935 Frank K. Walter indicated that he had three times as much material on hand for a dictionary of technical bibliographical terms as is included in his earlier book, even with Moth's supplement. In October of the same year, Louis Feipel of Brooklyn indicated a need for something more comprehensive than Cowles' glossary, published in 1933 by Bowker. Consideration of a new project must await publication of the "Glossary of Library Terms," scheduled for 1943.

\section{Biography-American Library Pioneers (Omnibus Volume)-College and Univer- sity Librarians}

Early in 1942 the Publications Committee decided to do nothing looking toward preparation of this volume until after the war. The chief of the Publishing Department suggested to the editor of the series that planning might be done as fast as the group could find time for it, as such manuscripts would not go out of date even though held for publication.

Book List-Buying-College LibrariesAnnual Supplement to Shaw Supplement Book List-Buying-Variant Titles

Mr. Feipel of the Brooklyn Public Library expresses a need for a list of books 
that have been published under variant titles.

"Booklist"-College and University Libraries-Scholarly Publications

Some preliminary discussion of a book selection tool for scholarly publications was held at the New York conference. A committee to study the proposal made a report to the A.C.R.L. in September 1940.

\section{"Booklist"-College Libraries-Undergrad- uate Level}

A current book selection guide for college libraries has been proposed. It has been discussed by the Editorial Committee and the College Library Advisory Board separately and jointly. It was last discussed by the College and Reference Section at the New York Conference. The secretary of the A.L.A., the chairman of the Editorial Committee, a representative of the C.L.A.B., and the chief of the Publishing Department made suggestions at the San Francisco conference about how this project might be started.

\section{College Libraries-Administration from the Standpoint of Control}

In response to a questionnaire sent out by the chairman of the Editorial Committee of 1936, several institutions expressed a need for a study of this subject comparable to the study which Ralph Dunbar made at the University of Chicago on the university library.

\section{College Libraries-Adult Education Services}

A suggestion for a book on alumni reading, submitted by John Knickerbocker, librarian, Gettysburg College, led to the idea of a book in the college field, similar to Helping Adults to Learn, which would describe various aspects of adult education service given by college libraries.

\section{College Libraries-College President and His Library}

The College Library Advisory Board suggested this topic to President Robertson of Goucher College. He was obliged to withdraw his offer to prepare the manuscript when the war broke out. With the discontinuance of the C.L.A.B. and with the appearance of Branscomb's Teaching with Books, it has been decided to hold this project in abeyance.

College Libraries-External Relations of the Librarian and His Staff

At Midwinter, 1939, the Editorial Committee expressed interest in Charles Brown's proposal for a book on the general subject of external relationships of the college library staff.

\section{College Libraries-Finance and Accounting}

The librarian at St. Olaf College, Northfield, Minn., suggests the publication of an introduction to college library finance and accounting.

\section{College Libraries-Survey Manual}

This project, which came to a halt even before Peyton Hurt's death, should probably be revived. Initiative rests with the A.C.R.L.

\section{Educational Methods-Influence on Read- ing and Libraries}

Mr. Milam and Miss Hostetter returned from the meeting of the department of superintendence of the N.E.A. in 1935 with a suggestion that we consider the publication of a book on new methods in education which affect reading and the use of library materials. Inasmuch as the emphasis was to be in the college library field, the Board on Library Service to Children and Young People recommended that the Editorial Committee consult the C.L.A.B. After this item had appeared on the docket for two joint meetings of the Editorial Committee and the C.L.A.B., it was shelved for the time being.

\section{Ephemera}

There was once a plan of the Social Science Research Council and the Joint Committee on Materials of Research to treat ephemera in one monograph. Subjects to be covered were: maps, pamphlets, clippings, manuscripts, music (possibly under such headings as sheet music, records, etc.), films, posters, broadsides and dodgers, pictures (picture collections and art collections). This was to be one large monograph with chapters on various subjects. 
It was to deal with the collection, care, organization (cataloging and classification), methods of preservation, how to keep the collection alive, weeding, etc. In Dr. Kuhlman's opinion it would not duplicate to any extent the series on the cataloging of special collections proposed by the Cataloging Committee. Something in this field may still need to be done.

Historical Collection-Organization and Preservation of Material

The need for a brief manual on the subject of historical manuscripts, their collection, organization, and preservation, has been expressed to Dr. Kuhlman by Miss Julia Schmitz of Whitman College Library, Walla Walla, Wash. Dr. Kuhlman passed the suggestion on with his endorsement.

\section{Index-Guide to Bibliographies of Foreign Theses}

Professor Palfrey and Mr. Coleman have done considerable work toward the preparation of a guide to foreign theses. The project is at a standstill because of the world situation.

\section{Index-Rare Books (Articles Dealing with)}

During the year 1939-40 the Bibliography Committee approved in principle the preparation of an index to periodical articles dealing with rare books, book collecting, first editions, etc. Further exploration was recommended to see if such an index could be incorporated in some other publication.

\section{Index-Subject List of Serials}

Mrs. Barbara Cowles is presumably still working on a manuscript (I 400 pages) which will list by subject the titles appearing in the Union List of Serials. Our latest information does not indicate whether Mrs. Cowles is working on titles listed in the original Union List. . . or whether she will use the second edition of the Union List . . . as a basis for her project.

\section{Manuscripts}

A by-product of Dr. Kuhlman's study of ephemera for the Social Science Research Council and the Joint Committee on $\mathrm{Ma}$ terials for Research was to have been a treatment of manuscripts. According to Dr. Kuhlman this would not overlap the project listed under the title "CatalogingSpecial Collections-Manuscripts" to any great extent.

Public Documents-History of the U.S. Depository System

At the Midwinter meeting, 1937, Dr. Kuhlman reported that he had almost completed a manuscript on "The History of the U.S. Depository System." $\mathrm{He}$ believes it to be basic literature which is much needed and which would be used by document librarians as well as by library schools. He believes the initial sale might be 250 to 350 copies the first year with a continuing, although abated, sale in the years following.

\section{Reading in Colleges}

A need has been expressed for a report and an evaluation of studies of reading interests and habits of college students. Any attempt to fill this need might overlap to some extent the project listed under the title "Educational Methods-Influence on Reading and Libraries."

\section{Resources-Pacific Southwest}

Willis Kerr, librarian of the Claremont Colleges Library, who is chairman of a committee of professors and librarians of the Association of Colleges and Universities of the Pacific Southwest, may submit to the A.L.A. for publication the report of a survey now under way of library resources in the Pacific Southwest. It is expected that a subsidy will be necessary to help finance the publiction.

\section{Resources-Rarities}

A letter from C. Stewart Peterson, I49 W. 84th St., New York City, to Mr. Milam, dated Nov. 2, 1935, asks for assistance in completing a bibliography of specially significant and highly treasured manuscripts, old maps, and first editions in the United States.

\section{Resources-Southern Libraries (Supple- ment)}

Under the sponsorship of the Board on Resources of American Libraries, a Sub- 
committee for the South has been engaged in preparation of a supplement to Resources of Southern Libraries. The supplement would endeavor to bring the record of acquisitions up to date.

\section{Resources-Special Collections}

Suggested in excerpt from appendix to accompany minutes of the meeting of A.L.A. Committee on Resources of American Libraries, Nov. I1, 1935.

"Handbook of Special Collections."

\section{Resources-Union Catalogs}

There are suggestions in file from Lawrence College, Western Reserve University, and the University of Illinois, pointing to the need for union catalogs and regional lists. Some are for material in specific subjects; some are for serials.

\section{Resources-Union Lists}

Suggested in excerpt from appendix to accompany minutes of the meeting of A.L.A. Committee on Resources of American Libraries, Nov. I I, I 935.

"Check List of Union Lists." Annotated checklist of all union lists (printed or manuscript) to be issued in printed form.
Training-Integration of Library Instruction in Teachers College Curriculum

This matter was discussed briefly in 1935 by the Joint Committee of the A.L.A. and the A.A.T.C. The Joint Committee report published in 1936 with Miss Fargo's curriculum outlines gives little attention to integration, according to Miss Hostetter. We have written Miss Fargo for reactions to the matter discussed originally by the Joint Committee. Her reply is in file.

Members of the Association, section chairmen, and committee chairmen are urged to comment on these projects and to suggest to the Publications Committee:

a. Which are the most important for immediate consideration?

b. What preliminary steps would be likely to produce the best finished work in a reasonable time?

Ruth BIRD

Ethel M. Feagley

ARdis Lodge

Clarence S. Paine

RALPH R. ShaW

Wharton Miller, ex officio

Carl M. White, ex officio

GUY R. LyLE, chairman

\section{A.C.R.L. Membership, 1939-42}

At the January meeting of the A.C.R.L. Board of Directors it was suggested that these figures, taken from the secretary's report, on the membership of A.C.R.L. by sections be submitted to the editors for publication in an early number of College and Research Libraries:

\begin{tabular}{lrrrr} 
Sections & 1939 & I940 & 1941 & 1942 \\
Agricultural & & & 104 & 94 \\
College & 230 & 329 & 490 & 470 \\
Junior College & 33 & 60 & 80 & 183 \\
Reference & 203 & 226 & 501 & 551 \\
Teacher Training & 85 & 129 & 152 & 186 \\
University & 186 & 321 & 545 & 479 \\
General & & 9 & 343 & 141 \\
\cline { 5 - 5 } & & & & \\
Totals & 737 & 1074 & 2215 & 2104
\end{tabular}


East

Members of the staff of the Pennsylvania State College Library, Willard P. Lewis, librarian, are making a significant contribution to the war effort by cooperating "beyond the line of duty" with war research projects on the campus. The staff of the Chemistry and Physics Library, for example, has assumed responsibility for surveying the literature useful to the projects in their fields, thus releasing faculty members to the more important laboratory work. Raymond R. Dickison is librarian of the Chemistry and Physics Library.

An A.K.R. Memorial Collection has been established in the library of Goucher College, Baltimore, Eleanor W. Falley, librarian. The collection is in memory of Mrs. Anne Knobel Robertson, wife of Goucher's president. Over five thousand dollars have been pledged and will be used to buy the kind of books Mrs. Robertson enjoyed.

The University of Rochester Library, John R. Russell, librarian, has received the research library of Dr. Ira S. Wile, an alumnus of the university. The collection includes about five thousand volumes in the fields of anthropology, sociology, comparative religion, medicine, and psychiatry. There are many interesting rarities, first editions, and association copies. Additions to the collection will continue to be made by the donor.

The Library of the Drexel Institute of Technology, Marie Hamilton Law, librarian, issues semimonthly a book-bulletin for distribution to its faculty. The bulletin contains a list of new accessions, annotated lists of books on timely subjects, and other information of interest to the faculty.

\section{News from}

Brown University Library, H. B. Van Hoesen, librarian, has received from Frederick S. Peck a collection of manuscripts which includes ten letters by Simon Bolivar written in I823. A gift of broadsides from Mr. Peck included the first publication abroad of "Yankee Doodle" and "Back-Side Albany," the earliest known song written in American Negro dialect.

The staff association of the Pennsylvania State College Library studied at its program meetings this year the administration of the library against the background of the theory and practice of other libraries. The program was based on a seminar in university library administration given by Dr. W. W. Bishop at the University of Michigan. Younger members of the staff gave papers and the entire staff took part in discussions.

The Friends Historical Library of Swarthmore College, Frederick B. Tolles, librarian, has received a collection of seventy-seven manuscript letters from John Murray, Jr., of New York, to James Bringhurst, of Philadelphia, I 787-1806. It has also acquired recently a special collection of books, pamphlets, and manuscripts relating to the Friends.

The Carl Schurz Memorial Foundation is building up the documentary tools necessary to make it the center for information on German-American materials and to this end is compiling a subject catalog, "Union Catalog on Americana-Germanica," which numbers at present thirty thousand cards.

The Philadelphia Museum of Art announces the opening of the Archives of American Art. The archives are a repository where artists' letters and papers 


\section{the Field}

and all documents which throw light upon the artist's life and opinions are preserved. The museum is prepared to receive, store, and make available any such documents and solicits the cooperation of American research libraries.

The Library of the School of Veterinary Medicine of the University of Pennsylvania is preparing a bibliography of veteripary medical periodicals published in the Americas. It is also preparing a subject list of motion pictures on veterinary medicine.

The Philadelphia Bibliographical Center announces the publication of Union List of Microfilms, Supplement I (1942). This supplementary volume of 244 pages lists about three thousand items reported since the publication of the main volume. Rudolph Hirsch is director of the Bibliographical Center.

The Library of Congress has received as a gift from Lessing J. Rosenwald a magnificent collection of rare books and manuscripts. In the collection are the finest examples of the book making art, including productions of early presses, embellished by famous artists and bound by great craftsmen. The collection includes fine copies from the fifteenth century presses of Germany, France, Italy, the Low Countries, and England, and also many of the outstanding productions of the modern great typographers. The collection from the early presses includes such volumes as Biblia Latina, 1462, The Pynson Chaucer, of I542, and several Caxtons.

The William Robertson Coe Collection of Western Manuscripts has been given to the Yale University Library by $\mathrm{Mr}$.
Coe. The collection, which is probably one of the most extensive and finest in existence, contains holograph letters, diaries, law books, and official documents on the Spanish voyages to the Pacific coast in the eighteenth century, the overland expeditions of the early nineteenth century, the early missions, particularly in the Oregon country, the Forty-Niners, the Mormon trek to Utah and their early difficulties, Indian wars, and the early histories of nearly all of the Western states.

The Library of Congress can now supply duplicates of its folk song records to libraries and the public. With the assistance of a grant from the Carnegie Corporation it has prepared seven albums containing I I 9 titles selected as being the best and most representative of the approximately thirty thousand recorded songs in the archives, and these are now ready for general distribution. These recordings were made in the field by such folklorists as Alan Lomax and his father, John Lomax. A catalog may be obtained by writing to the Archive of American Folk Songs, Music Division, Library of Congress, Washington, D.C.

The New York Academy of Medicine Library, New York City, has received one hundred and twelve editions of The Vicar of Wakefield by Oliver Goldsmith. The collection is a gift of Mrs. Lesta Ford Clay in memory of her father, Dr. Linsly R. Williams, a former director.

A catalog of Chinese Local Histories in the Library of Congress has just been published by the Library of Congress. It is a compilation of 584 pages, prepared by Chu Shihchia, a cataloger in the Chinese collection of the Asiatic division, and includes nearly three thousand histories of Chinese localities. 
Emory University Library has received $\$ 10,000$ from the estate of the late Dr. J. M. McCandless, of Santa Monica, Calif. The income from this fund will be used for the purchase of books in education, supplementing a collection established by Dr. McCandless in honor of his mother, Fanny McCandless, a pioneer teacher in South Carolina and Georgia.

The Rollins College Library, Joseph D. Ibbotson, librarian, is being reclassified, using L.C. schedules.

The manuscript and rare books collections of the Emory University Library, Margaret M. Jemison, librarian, have been moved to a newly completed Treasure Room on the main floor of the building. Manuscripts and printed materials of the Confederacy and of prominent Methodist leaders from the time of the foundation of the church to the present are particularly strong. The special collections are under the direction of Richard B. Harwell.

One of the oustanding new college library buildings of the South is that of Davidson College in North Carolina, Chalmers G. Davidson, librarian. The new building, housing forty thousand volumes and costing $\$ 150,000$, was completed in the spring of 1942. The book stacks, to which all Davidson students have access, are equipped with carrells and consultation rooms for students and professors. Three interesting collections of the library relate to Woodrow Wilson, who was once a student at Davidson, to Peter Stuart $\mathrm{Ney}$, and to books written by and about alumni of the college.

Bulletin No. 15 of the Friends of the University of Florida Library was issued in January. It is concerned chiefly with the role of the university library in the university community but contains news about library development on the campus and about gifts received from Friends.

Lincoln Memorial University, Harrogate, Tenn., has dedicated a Civil War Memorial Room. This room now contains an extensive collection of letters, manuscripts, and documents relating to the Civil War and to Lincoln.

Southwest

The Trinity University Library of San Antonio now contains approximately thirty-one thousand volumes. Trinity University of Waxahachie, Texas, was merged with the University of San Antonio in 1942. Several significant gifts have been received since the two libraries were brought together. Mrs. Thomas B. Simms is librarian.

Southwestern Baptist Theological Seminary, Seminary Hill, Texas, L. R. Elliott, librarian, is continuing its program of acquiring early religious periodicals on microfilm. In cooperation with other librarians and professors of church history, Mr. Elliott is laying the groundwork for attempting a union list of North American Baptist periodicals.

Surveys are being made of the library facilities of Fort Worth, Denton, and Dallas, Texas, with a view to undertaking a regional catalog for the three towns. The catalog will include college, university, and public libraries.

The papers of the Historical Records Survey of Arkansas have been deposited in the University of Arkansas Library, Marvin Miller, librarian. The collection includes transcriptions and listings of church, county, city, and court records, all of which are available for consultation. 


\section{Middle West}

The University of Wisconsin Library, Gilbert H. Doane, librarian, has received the collection of the late William Ward Wight, of Milwaukee, pertaining to the lost Dauphin of France. Also included in the collection are several hundred titles relating to eighteenth century France, including memoirs of prominent and obscure persons of the French court of that period. The collection was presented to the university by Elizabeth Wight, the owner's daughter.

The Indiana-Oakleaf Collection of Lincolniana, of Indiana University Library, was formally opened on February 13 in the presence of scholars, friends of the university, and state officials. Among the gifts received during the day were funds from the Ball Brothers Foundation at Muncie for the purchase of the Paul F. Coster collection of books, manuscripts, and pictorial matter relating to Abraham Lincoln and for the purchase from Frederick A. Meserve of the complete set of photographs relating to Abraham Lincoln and other personages connected with the Civil War. The foundation also presented a portrait of Abraham Lincoln painted by Jesse Atwood in 186o. Robert A. Miller is librarian of Indiana University.

\section{West}

The University of Oregon Library, Willis C. Warren, librarian, has completed assembling a photostat copy of The Oregon Spectator, the first newspaper on the Pacific Coast, which was published at Oregon City Feb. 5, I846, to Mar. Io, I855. No complete set of the original numbers is available.

The war information desk of the Los Angeles Public Library continues to serve population groups not usually reached by libraries. Faith Holmes Hyers' popular War Queries column in a Los Angeles newspaper, which is based on questions asked at the war information desk, stimulates readers to send in their questions and problems.

The Colorado College and $\mathrm{Head} \mathrm{Li}-$ brarians Conference has established a Joint Committee for the Study of Basic Problems in Technical Processes, $W y$ yllis E. Wright, chief cataloger, New York Public Library, chairman. The committee will serve as a correlating agent for research in the field of the technical processes. The needs of the users of the catalogs, the types of information that should be given in records, the administrative organization of acquisition and cataloging departments, and the possibilities of better and cheaper cataloging through cooperative means are topics on which the committee hopes to stimulate research. Inquiries may be addressed to James G. Hodgson, secretary, Colorado State College Library, Fort Collins.

\section{Personnel}

Emily Miller Danton has been appointed acting director of the Sullivan Memorial Library of Temple University, replacing her husband, J. Periam Danton, who has been given a leave of absence to accept a commission in the United States Naval Reserve.

Oscar C. Orman, librarian of Washington University in St. Louis, has been granted a leave of absence to accept a commission of lieutenant ( $\mathrm{jg})$ in the United States Naval Reserve.

W. Francis English has been appointed assistant professor of history and director of the Western Historical Manuscripts Collection at the University of 
Missouri. The collection is a joint project of the department of history, university library, and State Historical Society of Missouri.

John J. Lund, librarian of Duke University, has been given a leave of absence for the duration of the emergency. $\mathrm{He}$ is engaged in defense work on the West Coast.

Lorena A. Garlock has been appointed acting librarian of the University of Pittsburgh, to replace Carroll F. Reynolds, who is now employed in a war industry.

Clyde H. Cantrell, formerly circulation librarian at North Carolina State College, is now assistant librarian at West Virginia University, W. Porter Kellam, librarian.

Bernhard Knollenberg, the librarian of Yale University, has been given a leave of absence and is now Senior Deputy Administrator of Lend-Lease in Washington.

Mary Lyle Vincent, formerly cataloger at the Georgia State College for Women, has been appointed librarian at San Angelo College, in Texas.

Lawrence C. Wroth, librarian of the John Carter Brown Library, Providence,
R.I., has been appointed consultant of the Library of Congress in the acquisition of rare books. He will retain, however, his post as librarian of the John Carter Brown Library.

Father B. E. Moll, librarian, St. Benedict's College, Atchison, Kan., has been granted a leave of absence to serve as chaplain in the Army.

William D. McCain, director of the Mississippi State Department of Archives and History, has been commissioned a first lieutenant in the Army and has been granted a leave of absence for the duration of the war. Charlotte Capers, research and editorial assistant in the department, will serve as acting director during $\mathrm{Mr}$. McCain's absence.

Georgia Coffin has resigned as librarian of Huie Library of the Henderson State Teachers College, Arkadelphia, Ark., to accept a position in the University of Illinois Library. Mrs. R. W. Huie, Jr., has been named acting librarian for the spring semester.

Frederick Cromwell, for the past year acting librarian of the University of Arizona, has been appointed librarian.

\section{University of Chicago Institute}

THE University of Chicago Graduate Library School's eighth institute will be devoted to the public library in its community relationships and will be held during the week of August 23-28. The program will emphasize the sociological backgrounds and structures of cities, small towns, and rural regions and their interrelationships with library activities; methods of community survey and analysis; the needs of special community agencies and population groups; the nature of community services and obligations imposed by the war ; and the role and responsibilities of the library in the community of the future.

A registration fee of five dollars will be charged for all persons enrolled in the institute except regular students in the Graduate Library School. Registration may be made in advance by writing to the school. 


\section{MINUTES OF THE MEETING OF THE BOARD OF DIRECTORS OF A.C.R.L., CHICAGO, JANUARY 3 I AND FEBRUARY I, I943}

The meeting of the Board of Directors of the Association of College and Reference Libraries was called to order at 8 P.M., Jan. 3I, 1943, at the Drake Hotel, Chicago. The directors present were: President Mabel L. Conat; Secretary Benjamin E. Powell; A.C.R.L. Directors Etheldred Abbot and Willis H. Kerr; Section Directors Fina C. Ott, of College Libraries, and Lois E. Engleman, of Junior College Libraries. Section chairmen present were: Harold Lancour, Engineering School Libraries; Wave L. Noggle, Junior College Libraries; Mary N. Barton, Reference Librarians; Eleanor W. Welch, Libraries of Teacher Training Institutions; and John J. Lund, University Libraries. Hazel Armstrong, A.C.R.L. representative on the A.L.A. Council, was present by invitation. Others attending by special invitation were Frances $W$ arner and Florence Gifford, of the A.C.R.L. Committee on Wartime Activities; Flora B. Ludington, Hazel B. Timmerman, and Paul North Rice, of the Committee on Budgets, Compensation, and Schemes of Service; Ralph E. Ellsworth, chairman, A.C.R.L. Committee on College and University Library Buildings; Thomas P. Fleming, A.L.A. Committee on Importations; Guy R. Lyle, A.C.R.L. Publications Committee; Carl M. White, editor, College and Research Libraries; and Samuel W. McAllister, chairman, A.C.R.L. Committee on Constitution and By-Laws.

In view of publication in the December I942 issue of College and Research Libraries, the minutes of the last meeting were approved as published.

\section{Committee on Wartime Activities}

A general report of the committee was presented by Florence Gifford and Frances Warner, who represented Charles $H$. Brown, chairman of the A.C.R.L. com- mittee, after which the recommendations of the committee were considered. Copies of College Libraries and the $W$ ar, compiled by Charles $H$. Brown and issued by the American Library Association as circular number 8 of Libraries and the $W$ ar, were distributed. The committee presented for the consideration of the board a suggestion that a publication devoted to college libraries and the war be prepared and published. Funds for such a study have been set aside by the American Library Association from a Carnegie Corporation grant to the A.L.A. for emergency activities. After discussion, it was

VOTED to authorize the preparation and publication of such a report as early as feasible.

It was further suggested by the board that the committee publish in such form as it shall agree upon, and as often as available material warrants, additional information about the wartime activities of college and university libraries.

The committee presented to the board without recommendation a statement on the deferment of librarians, a statement which if approved might be sent to the head of the Selective Service Bureau of the War Manpower Commission. This statement was prepared by the committee and the A.L.A. Board on Salaries, Staff, and Tenure in response to requests to A.L.A. that the question be discussed. There was general opposition to the board's sponsoring a request for the deferment of librarians, and after discussion it was

VoTED to reject the statement.

An excellent propaganda collection has been brought together by Mortimer Taube, of Duke University, and from it an interesting exhibit prepared. The committee pointed out that it would be highly desirable for such a collection to be exhibited in libraries throughout the country. Mr. Lund 
informed the board that it would not be practicable to lend the exhibit. $\mathrm{He}$ said, however, that a list of its contents might be prepared. The board recommended that if possible the committee secure a description of the Duke exhibit and include it in the publication describing wartime activities in college and university libraries.

The committee recommended that the A.C.R.L., through the directors, join the A.L.A. Board on International Relations in commending the action of the United States government in bringing many Latin American scholars and students to this country. It was

Voted that the A.C.R.L. join the A.L.A. Board on International Relations in sending such a statement of appreciation and commendation.

The committee expressed the hope that the new publication Victory, published by the Office of War Information for our men overseas, could be made available to libraries in this country, especially to depositories of government publications. The board authorized the committee to see what might be done about securing files for preservation in libraries of this country.

Recognizing the interest and value of the publication recently prepared and distributed by the A.C.R.L. Committee on Wartime Activities, it was

Voted that the A.C.R.L. board, through its president, express its appreciation to the A.L.A. Committee on Libraries and the War for making possible the publication of College Libraries and the War. Copies of the resolution are to be sent to President Metcalf and Secretary Milam.

The board was in unanimous agreement that the A.C.R.L. Committee on Wartime Activities should be continued, and its sphere was extended to include activities in college and university libraries relating to postwar planning.

Committee on Budgets, Compensation, and Schemes of Service

Since copies of "Classification and Pay Plans for Libraries in Institutions of Higher Learning" had been distributed in advance by the Committee on Budgets, Compensation, and Schemes of Service, the report of the committee was brief. It was presented by Flora B. Ludington, who represented the committee as acting chairman in the absence of the chairman and vice chairman. She explained that the report was not intended to regiment or to set up standards for college and university libraries. Its mission is to be information rather than legislation. It is designed as a guide for the librarian wishing to evaluate his library. In the discussion which followed Miss Ludington's report, both Miss Ludington and $M$ iss Timmerman answered questions raised by members of the board. After considerable discussion and several minor suggestions, the board

VOTED to endorse the report but recommended that the report's objective be made clear in the introduction.

Ralph E. Ellsworth reported that the A.C.R.L. Committee on College and University Library Buildings has a subcommittee working on a study of divisional libraries. The advice of the committee is regularly sought by those contemplating building programs or alterations and by those in need of information on library furniture and equipment. The chairman realized the committee would not be active during the war period but suggested that it be continued, and it was so ordered.

Thomas P. Fleming, of the A.L.A. Committee on Importations, reported briefly on the efforts of his committee to secure certain 1942 foreign scientific publications and on plans for 1943. His informative, written report was accepted and a copy has been filed with the secretary.

Chairman Guy R. Lyle submitted the report of the A.C.R.L. Publications Committee as it appears in this number of College and Research Libraries. Each of the major headings was discussed and given a vote of approval, after which the board ordered that the full report be mimeographed and copies sent to section chairmen and representatives of section publication committees.

The statement of policy of the editors of College and Research Libraries, as it appeared in the March number of the journal, 
was approved as presented to the board by Editor Carl M. White.

Mr. White presented for the information of the board several other matters relating to publication activities. One of them called attention to the possibility of making College and Research Libraries an effective substitute for meetings during the war period. Subjects which in normal times would be discussed in section meetings will be treated in the pages of the quarterly. None of these matters called for official action, but members were asked to express their opinions and offer suggestions.

College and university library statistics for 1941-42 were compiled by volunteer assistants and were included in the March number of College and Research Libraries. $\mathrm{Mr}$. White raised the question of whether statistics should be compiled and published during the emergency and suggested that if so some permanent plans should be laid. The board

Voted that if possible these statistics be collected annually and published.

Upon motion, the meeting adjourned at I I :45 P.M., to meet in the same room at 2 P.M. on Monday.

\section{FebrUary I, 1943-2 P.M.}

The Board of Directors meeting was continued at 2 P.M. in the Drake Hotel. Those present were: Conat, Powell, Abbot, Kerr, Engleman, Armstrong, Ott, Barton, Lancour, Noggle, and Welch, of the previous meeting, and Past-President Donald Coney, who was able to stay for only a part of the meeting.

Miss Conat called attention to the discontinuance of the substitution plan for College and Research Libraries and Handbook and Proceedings. After some discussion, it was agreed to let the matter rest.

Miss Barton suggested that the A.L.A. membership forms should carry a blank space to be filled in by subscribers to $\mathrm{Col}$ lege and Research Libraries. The idea was also advanced that more members of A.L.A. would check division and section choices if the names of each were printed on the front of the membership form. The secretary pointed out that the present form had been approved in 194I by the secretary and president of A.C.R.L. Nevertheless, it was recommended that the secretary look into the matter of working out with A.L.A. a revised membership form which should include checking space for members who wish to subscribe for College and Research $\mathrm{Li}$ braries.

The secretary read the report of Donald Thompson, chairman of the Periodicals Exchange Union, on the activities of this committee and its plans for the immediate future.

The secretary next reported on the growth of A.C.R.L. membership by sections from 1939 through 1942. A statement of this growth appears on page $26 \mathrm{I}$ of this issue of College and Research Libraries.

Copies of the report of the Committee on Constitution and By-Laws were distributed by Chairman Samuel W. McAllister. The committee had been asked by the board to consider the status of A.L.A. life members who might wish to become members of A.C.R.L. and its sections. The committee's report called attention to the constitution of the Division of Cataloging and Classification, which provides that those becoming life members of A.L.A. before 1940 may pay \$Io for life membership in the division; for those after July I, I940, \$2 per year shall be allocated by A.L.A. to the division.

The report was accepted, and the committee was authorized to prepare an amendment to the A.C.R.L. constitution providing for membership in A.C.R.L. of life members of A.L.A. along the same general plan as adopted by the Division of Cataloging and Classification. Life members of A.L.A., meanwhile, will continue to enjoy the same A.C.R.L. privileges as granted during the past two years.

With respect to the appointment of substitutes for absent councilors, the committee pointed to the A.L.A. provisions in its ByLaws, Article IV, Section V (a), and the provisions of the constitution of the Cataloging and Classification Division. Each provides that the president of the division can appoint a substitute for regularly elected councilors who cannot attend a meeting of the council. It was 
Voted that the President of A.C.R.L. be empowered to appoint substitutes for A.C.R.L. representatives on the A.L.A. Council who can not attend council meetings.

The treasurer was not present, but copies of the following report were distributed:

Income

Balance, Jan. I, 1942

Allotment from A.L.A.

Additional section choice

East Lansing State Bank-liquidation dividend

\section{Expenditures}

College and Research Libraries

Sectional expenses

Agricultural Libraries

College Libraries

Junior College Libraries

Reference Librarians

Teacher Training Institution Libraries

University Libraries

Committee expenses

Budget, etc.

Encyclopaedia of Sports

Other committees

Officers' expenses

President

Secretary

Treasurer

\section{Totals}

Unallocated balance

Total income, 1942

Total expenditures

Balance on hand, Dec. 31, 1942 were appointed by the president to serve as an Auditing Committee. After it was read by the secretary, the board

Voted to accept the report of the Auditing Committee.

Attention was next turned to the 1943 budget. After deliberation, it was

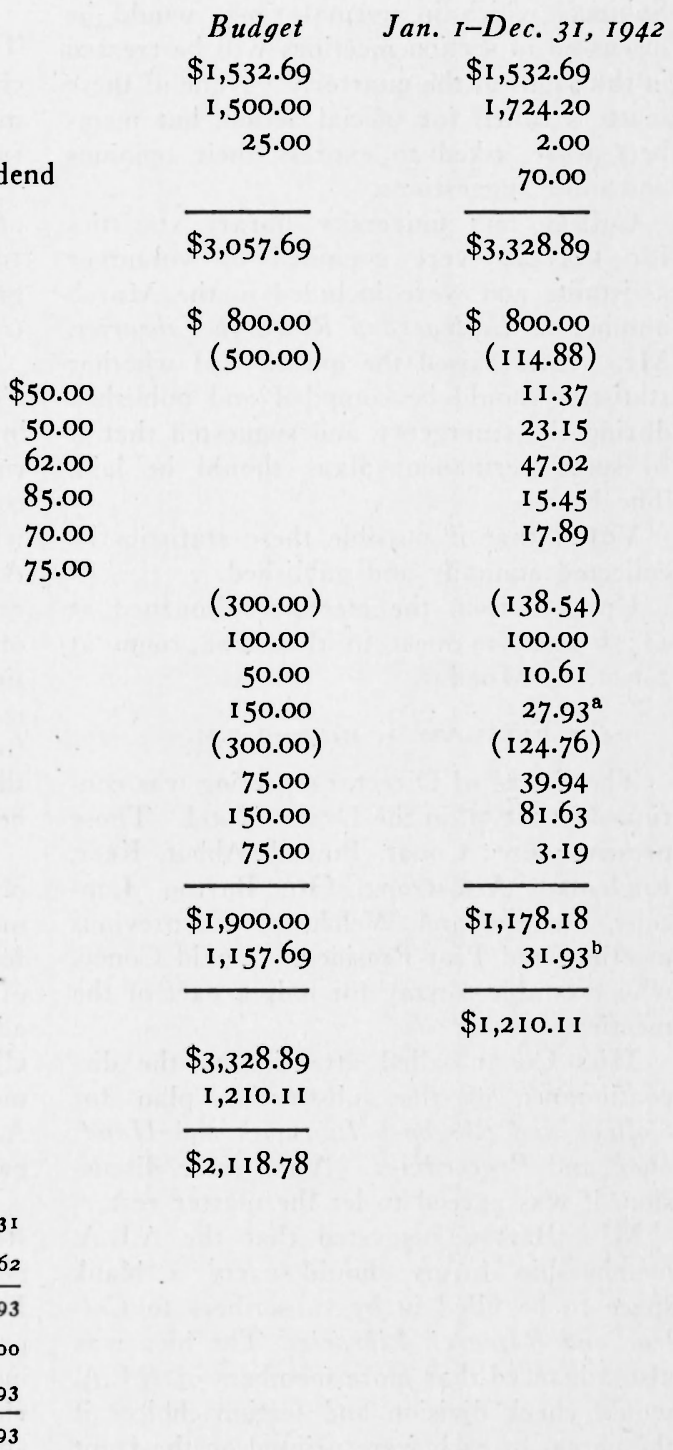

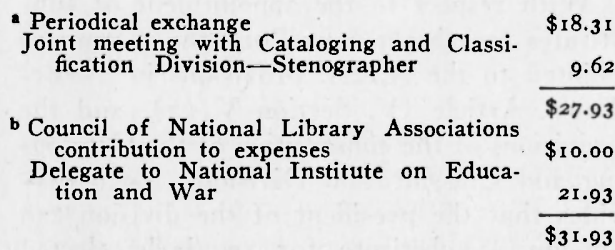

The Treasurer's accounts were audited by Robert B. Downs and Paul North Rice, who
Voted to approve the budget for 1943 as outlined below: 
Income

Balance, Jan. I, 1942

Allotment from A.L.A.

1943

Budget

I,500.00

Total

$\$ 3,618.78$

\section{Expenditures}

College and Research Libraries

Sectional expenses

Agricultural Libraries

College Libraries

Engineering School Libraries

Junior College Libraries

Reference Librarians

Teacher Training Institution Libraries

University Libraries

Committee expenses

Officers' expenses

President

Secretary

Treasurer

Total

Unallocated balance

75.00

150.00

75.00

$\$ 2,125.00$

$\$ \mathrm{I}, 493.78$
Following more discussion, in which the A.C.R.L. Board of Directors recognized both the autonomy of sections and the, demands of the national emergency, it was apparent that the continuity of section programs and activities might be better preserved, during this period, by the continuance in office of section officers. It was, therefore,

VOTED that the board recommend the "freezing" of section officers and nominations for the duration of the emergency. This action provides that present section offcers be continued until the next annual meeting, at which time the present nominees will be elected to office.

\section{Reports from Sections}

(300.00)

$(300.00)$

At the recommendation of the presiding offcer, it was

Voted that the president is authorized by the Board of Directors to appoint, as a standing committee, an Auditing Committee to check annually on the treasurer's report.

Attention was next turned to the vacancy on the A.L.A. Council created by the induction into the Navy of J. Periam Danton, one of A.C.R.L.'s representatives on the Council. It was

VотED not to fill the vacancy until the next election.

President Conat asked for a nomination from A.C.R.L. for the Board on Resources of American Libraries. Willis Kerr was proposed, and it was

Voted that Mr. Kerr be nominated for membership on this board.

In view of A.L.A.'s decision not to meet again during the emergency, the question arose as to the wisdom of electing A.C.R.L. and section officers this year. After much discussion it was agreed to hold the election of A.C.R.L. officers this year.
Fina C. Ott recommended that section chairmen keep their directors better informed about affairs of the sections. Many directors apparently feel that they have not been in a position to represent adequately the wishes of the sections at board meetings in the past. The board urged, therefore, that section chairmen establish some procedure to bring about closer relations between these officers.

The officers of the Junior College $\mathrm{Li}$ braries Section devoted much attention during the past year to a membership campaign. That the campaign was successful is reflected in an increase in membership from 80 members in 1941 to 183 in 1942 .

The Reference Section has appointed a committee to make a study of needed reference books, to stimulate the writing of referof reference work. The committee is making progress.

The Libraries of Teacher-Training Institutions Section has also been concerned with membership and has increased its number from 152 in 1941 to 186 in 1942 . A committee has been appointed to make a study of in-service training.

The new Engineering School Libraries Section now has a membership of 58 members representing 39 institutions. It is issuing a news sheet and has in preparation a directory of members. A project to survey the country for the holdings of Axis scienence articles, and to study the general field 
tific publications was started in 1942, but the work done by this committee has been turned over to the Library of Congress, which has expanded the program and will continue it along these expanded lines.

Through the secretary, the chairman of the University Libraries Section reported progress on its program related to postwar planning.

The Agricultural Libraries Section representatives were not present, but a written report was submitted by the chairman subse- quent to the meeting. The section reported that its officers for 1943-44 have already been elected. Attention is being given to the problem of exchanges, especially with respect to agricultural and scientific publications, and some plans whereby the smaller institutions will be helped will be worked out.

Upon motion, the meeting adjourned at 4:45 P.M.

Benjamin E. Poweld Secretary, A.C.R.L.

\section{University of Chicago Scholarships for Basic Curriculum in Librarianship}

The Graduate Library School of the University of Chicago will offer two fulltuition (\$300) scholarships and two halftuition (\$150) scholarships for the academic year 1943-44 for students enrolled in the new basic curriculum leading to the bachelor of library science degree. The new program will begin in the autumn quarter of I943. The scholarships now offered are in addition to the fellowships previously announced for advanced study at the school.

The new program is planned as follows:

I. For students with a bachelor's degree, a one-year program of basic courses in library techniques, with additional courses in a subject field related to the special library interest of each student.

2. For students with two years of college, a three-year program, including two years of preprofessional courses in subject fields followed by one year of basic library courses.

Students in either of the above groups are eligible to apply for scholarships. Applications must be in the hands of the dean of the Graduate Library School by June I 5, I943.

Application forms for scholarships and for admission to the school may be obtained by writing to the Graduate Library School, University of Chicago. 